\title{
Stage I Renal Cell Cancer AJCC v8
}

National Cancer Institute

\section{Source}

National Cancer Institute. Stage I Renal Cell Cancer A/CC v8. NCI Thesaurus. Code

C140323.

Stage I includes: T1, N0, M0. T1: Tumor measuring $7 \mathrm{~cm}$ or less in greatest dimension, limited to the kidney. N0: No regional lymph node metastasis. M0: No distant metastasis. (AJCC 8th ed.) 